DOI: $10.22616 /$ REEP.2019.020

\title{
Some Aspects of Motivating Tertiary Students in Learning Oriental and European Languages
}

\author{
Victoria Safronova ${ }^{1} \mathrm{PhD}$; Evgeniya Klyukina ${ }^{2}$ \\ Lomonosov Moscow State University, Russia \\ vika-avril@yandex.ru; ${ }^{1}$ eugenialex@mail.ru²
}

\begin{abstract}
Motivation as a concept, motivating factors and the role of the teacher in the motivation mix have received considerable attention lately. Tertiary students seem to be the ones who have potent intrinsic motivation simply because completing a degree is not compulsory. Nevertheless, motivation is seen to be directly related to learners' performance and achievement. Thus, the study attempted to explore motivating factors for tertiary students in a specific educational setting - in a college where they are supposed to take up two foreign languages and study them both from scratch (or at best to continue one from of them from an intermediary level) simultaneously, the task made more challenging by the fact that the major language is an Oriental or an African one. Therefore, the aim of the study was to question the students about their perception of the motivating factors, including the importance of the figure of a teacher and the teacher type related to authoritarianism versus a more democratic management style; gender-related differences, if any, were of particular interest, as well as those concerning particular languages, namely European languages vs oriental ones. For this purpose, a questionnaire was devised, printed out and distributed among the students. The responses, which were given in the teachers' absence, were subsequently collected and analysed. The results of the survey suggest that intrinsic motivation is indeed the prevalent form of motivation for tertiary students in both Oriental/African and West European language, though the role of the teacher and relevant interesting materials and topics for discussion help foster the intrinsic motivation. A more democratic style of class management is seen by the students as preferable and more conducive to language learning.
\end{abstract}

Keywords: motivation, educational process, tertiary education, Oriental/West European languages.

\section{Introduction}

Much has changed in the modern classroom starting with the shift from teacher-centred to studentcentred environment. Much has changed about the content which has received a major makeover. Technological tools, which are supposed to appeal to digital natives, have become an integral part of teaching and learning. Motivation has been actively researched and analysed having become one of the main elements of effective teaching. What has changed about the teacher and the teacher's role? Is the teacher a provider of knowledge or a facilitator of learning? Is the teacher the one who knows how to teach? Or is it the one who knows how to learn? It is assumed that teachers change and adapt accordingly with the change in approaches and teaching styles. Do they? What motivates students to learn? And what traits, abilities and attitudes do modern students wish to see in their teachers?

According to R.C. Gardner (Gardner, 1985), back in the 1950-s learning a foreign language was considered to be a matter of intelligence and verbal ability. Not much attention was given to such concepts as motivation or language anxiety. After all, if a foreign language was on the curriculum the students were just supposed to learn it. Now motivation in foreign language learning in general and willingness to communicate in particular has received a lot of attention. Motivation as a multi-faceted concept, though, has proven to be particularly elusive and hard to define. According to Z. Dornyei, we seem to have some intuitive understanding of motivation, though so far, no motivational theory has succeeded in providing a comprehensive definition of what motivation is (Dornyei, 2011). As for willingness to communicate, it seems to be easier to grasp and is defined as "a learner's readiness to enter into discourse at a particular time with a specific person or persons using a L2" (MacIntyre et al., 1998).

Perhaps, the most common distinction in motivation theories is that of intrinsic versus extrinsic motivation, the former being the one which involves activity carried out for its own sake and satisfaction, pleasure and joy associated with it. The second type deals with behaviour which is aimed at receiving some extrinsic reward (e.g. good grades) or at avoiding negative consequences such as punishment (Dornyei, 1998). 
In a practical sense motivation has been dissected into several components - Language Level, Learner Level, Learning Situation Level (Course-Specific Motivational Components and Teacher-Specific Motivational Components) and finally Group-Specific Motivational Components (Dornyei, 1994). "Teacher specific motivational components concern the teacher's behaviour, personality and teaching style, and include the affiliative motive to please the teacher, authority type (authoritarian or democratic teaching style), and direct socialization of student motivation (modelling, task presentation, and feedback)" (Dornyei, 1998).

R.C. Gardner's motivational theory distinguishes two major orientations - integrative and instrumental. The former concerns "motivation to learn a second language because of the positive feelings toward the community that speaks that language". Instrumental orientation refers to "the practical value and advantages of learning a new language" (Gardner, Lambert, 1972) and is often associated with a practical or pragmatic benefit such as a better job or higher salary.

The textbook authors and publishing houses have been doing their utmost to create teaching materials which are relevant and interesting, to design tasks which are challenging and engaging. Why then do some foreign language learners shy away from speaking up in a classroom environment that is specifically designed to foster communication? And what is the role of the teacher in motivating their students to put effort into learning a foreign language generally and engage in communication in a foreign language in class in particular? The importance of the teacher role was largely ignored until quite recently, perhaps, because it was commonly taken for granted that the teacher is the person who received formal training in employing the best possible strategies for their students' achievement.

Basing on his own experience and involvement in professional relationships J.A. Polk writes about traits of effective teachers and singles out "ten basic characteristics of effective teachers: good prior academic performance, communication skills, creativity, professionalism, pedagogical knowledge, thorough and appropriate student evaluation and assessment, self-development or lifelong learning, personality, talent or content area knowledge, and the ability to model concepts in their content area" (Polk, 2006).

These traits are interrelated, for instance, elaborating on the necessity of life-long learning, J.A. Polk emphasizes that "a teacher's passion for teaching and learning does not go unnoticed by students. By continuing to seek out learning opportunities, teachers continue to serve as models of what a learner should be (Polk, 2006).

The review of recent studies suggests that effective teachers know the subject matter and behavioural strategies concerning class management, they teach enthusiastically and energetically, using a high degree of intensity. "Teacher intensity refers to a global level of enthusiasm and other behaviours, such as maintenance of eye contact, closeness to students, voice use, and gestures and expressions" (Madsen, Standley, Cassidy, 1989). In several studies a teacher was ranked as more effective and interesting thanks to their enthusiastic manner even if the content of the lesson was poor or inaccurate (Hamann et al., 2000; Madsen, 2003).

R.C. Gardner generalizes that language teachers must have knowledge of the language and skills to operate it. At the same time it implies that they have enough proficiency to teach the language because the students are quick to see through the teacher who does not have sufficient proficiency. Besides the teacher is supposed to have the necessary training alongside personality traits and abilities in order to not only to teach the language but also to motivate the students to acquire the knowledge and use it (Gardner, 2001).

Many researchers have commented on teacher personality and how it correlates with effectiveness, for example, R.P. Cantrell, A.J. Stenner and W.G. Katzenmeyer concluded that more effective teachers are (a) more knowledgeable from a behaviour theory standpoint than one likely to espouse primitive, controlling strategies for dealing with pupils; (b) much more positive, supportive, and comfortable with pupils than authoritarian; and (c) more likely to use a higher rate of praise or encouragement statements and to ask more questions while still being moderately directive in the classroom" (Cantrell, Stenner, Katzenmeyer, 1977).

W. Sanders and S. Horn suggest that "the effectiveness of the teacher is the major determinant of student academic progress. Teacher effects on student achievement have been found to be both additive and cumulative with little evidence that subsequent effective teachers can offset the effects of ineffective ones" (Sanders, Horn, 1998). 
Despite a wealth of literature on effective teaching and traits of effective teachers, questions still arise whether all the teachers are willing to adapt.

"In typical classrooms, the most important asymmetry in the rights and obligations of teacher and students is over control of the right to speak. To describe the difference in the bluntest terms, teachers have the right to speak at any time and to any person; they can fill any silence or interrupt any speaker; they can speak to any student anywhere in the room and in any volume or tone of voice" (Cazden, 2001).

Moreover, teachers feel that they are not supposed to explain their choices to their students be it a choice of materials to be used in class, a choice of tasks to be done or a choice of students to be asked and grades to be given. Even democratically-minded teachers are in this respect autocratic.

C. Cazden also writes about the importance of a shift from "recitation to something closer to a "real discussion" in order to treat topics that do not fit the lesson structure". She advocates classes which provoke discussion and exploration rather than answering the teacher's questions though the latter are certainly easier to evaluate and grade. She stands up for lessons in which teachers talk "less than the usual two-thirds of the time and students talk correspondingly more; in which students themselves decide when to speak rather than waiting to be called on by the teacher; and in which students address each other directly" (Cazden, 2001).

In "Ten Commandments for Motivating Language Learners" Z. Dornyei and K. Csizer give what they call macro strategies aimed at enhancing the students' motivation:

- set a personal example with your own behaviour;

- create a pleasant, relaxed atmosphere in the classroom;

- present the tasks properly;

- develop a good relationship with the learners;

- increase the learners' linguistic self-confidence;

- make the language classes interesting;

- promote learner autonomy;

- personalize the learning process;

- increase the learners' goal-orientedness;

- familiarize learners with the target language culture (Dornyei, Csizer, 1998).

In fact, all the commandments concern the teacher and their professional behaviour in the classroom. After all, it is the teacher's responsibility to provide interesting material for the language classes, to enhance the students' autonomy, to make sure the learners are oriented towards specific and measurable goals and to provide a proper presentation of tasks. But for the purposes of this particular study only three commandments - 1,2 and 4-were focused on. The teacher is obviously the most important role model in the classroom. Is helshe interested in the subject matter they teach? Is this interest contagious for the students? Do the students see the effort that the teacher puts into teaching? Attitude toward the learning situation is a key factor having an influence on motivation. Clearly, a tense classroom environment is hardly conducive to learning but rather tends to produce student anxiety. Practicing teachers are aware of the fact that "a good rapport between the teacher and the students is a basic requirement in any modern, student-centred approach to education" (Dornyei, Csizer, 1998).

Therefore, the aim of the study was to question the students about their perception of the motivating factors, including the importance of the figure of a teacher, the teacher type related to authoritarianism versus a more democratic management style; gender-related differences, if any, were of particular interest, as well as those concerning particular languages, namely European languages vs oriental ones.

\section{Methodology}

For this aim, a questionnaire was designed for the students of the Institute of African and Asian Studies, Lomonosov Moscow State University. The peculiarity of this college is that the students major in one of the specialties - economics, philology, political studies or history - and at the same time in one of oriental or African languages which they study from scratch (A1). According to the syllabus, the students are also supposed to take up a West European language as L3. For some students it is French, Spanish or German which is again studied from A1, though for some students it is English which they mostly continue to learn from B1-B2 levels. The number of academic hours given to an oriental/African 
language and a West European one differs significantly - the former is studied for 16 academic hours per week, while the latter for $6\left(1^{\text {st }}, 2^{\text {nd }}\right.$ and $4^{\text {th }}$ years $)$ and as few as $4\left(3^{\mathrm{d}}\right.$ year $)$. Thus, specializing in non-linguistic disciplines, the students are still supposed to have an extensive program in languages. The questionnaire comprised multi-choice questions in the students' native language - Russian - and pertained to their perception of their language proficiency level after completing secondary education, type of teacher personality and other motivating factors. The questionnaires were printed out and distributed among the students in class. The responses, which the students gave anonymously at their leisure, were subsequently collected and analysed. The questionnaires were completed and submitted in the teachers' absence.

Let us turn to the results of the survey conducted in the Institute of Asian and African Studies (IAAS) among the bachelor degree students of all the four years of studies majoring in one of the four specialties - history, political studies, economics or philology. As it was mentioned above, it would not be completely correct to call the IAAS a linguistic college because the students receive a classical education in oriental studies with a deep knowledge of languages which implies a large number of academic hours allotted for relevant oriental or African languages. The survey was conducted among 76 persons, with the method of accidental sampling being applied. The gender composition: females accounted for $72 \%$ (54 persons), males made up $28 \%$ (21 persons), among them: $1^{\text {st }}$ year -13 persons, $2^{\text {nd }}$ year $-18,3^{\text {d }}$ year - 13, $4^{\text {th }}$ year -32 persons. The languages the respondents major in included: Oriental/African (16) Arabic, Chinese, Vietnamese, Korean, Japanese, Mongolian, Hindi, Hebrew, Urdu, Farsi, Persian, Thai, Indonesian, Hausa, Amharic, Afrikaans; West European (4) - English, French, German, and Spanish).

\section{Results and Discussion}

When asked "What is the most important thing for you while learning a foreign language at University" the respondents chose (Figure1):

- Subject matter of materials and discussions in class - 39 persons $(51 \%)$

- Teacher -45 persons $(59 \%)$

- Atmosphere in class - 39 persons (51\%)

All in all the students were quite satisfied with the range of topics they were supposed to discuss during classes in both their European and Oriental languages - totally satisfied with the topics were 16 people (21\%) and 21 people ( $72 \%$ ) respectively, while the numbers of respondents who answered "rather yes than no" were 41 persons (53\%) and 26 persons (34\%) respectively.

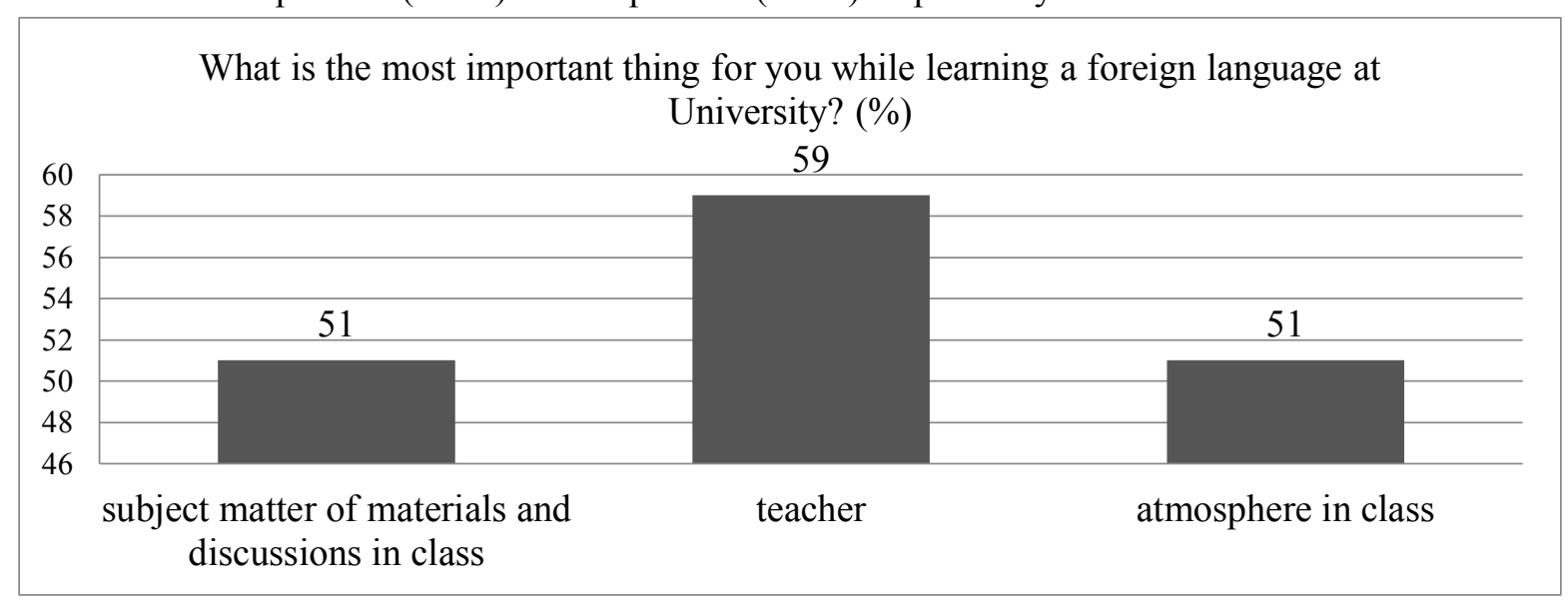

Figure 1. The most important factors for learning a foreign language.

The analysis of questions aimed at identifying the most interesting topics that stimulate intrinsic motivation which in its turn defines the learner's attitude to the subject matter and provides progress in their mastering of a foreign language showed the following results:

The larger part of the respondents $(72 \%)$ considers that pressing contemporary problems are the most interesting topic for discussion in class in both the oriental and European languages. (Figures 2, 3) The second place is divided among three topics: literature which accounts for $40 \%$, everyday life topics and politics account for $39 \%$ at the lessons in West European language, and history, politics and everyday life topics make up $52 \%$ for classes in an Oriental language. 


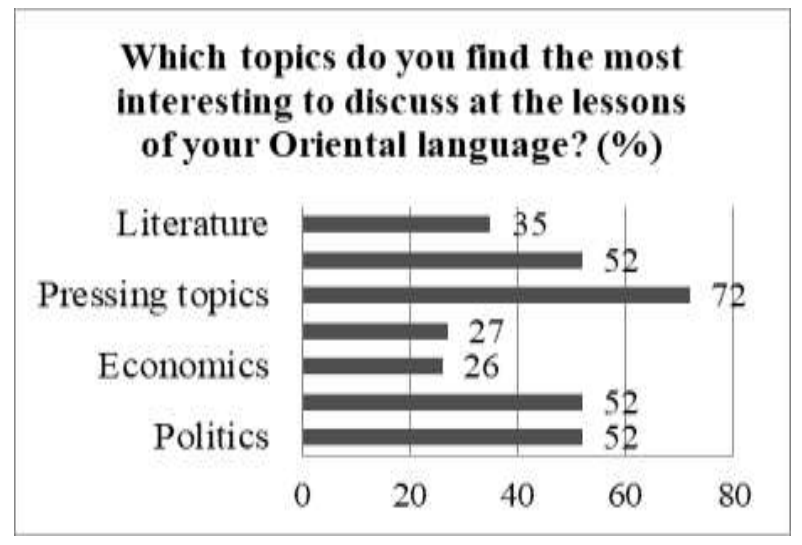

Figure 2. Most interesting topics in Oriental languages.

\section{Which topics do you find the most interesting to discuss at the lessons in your European language? (\%)}

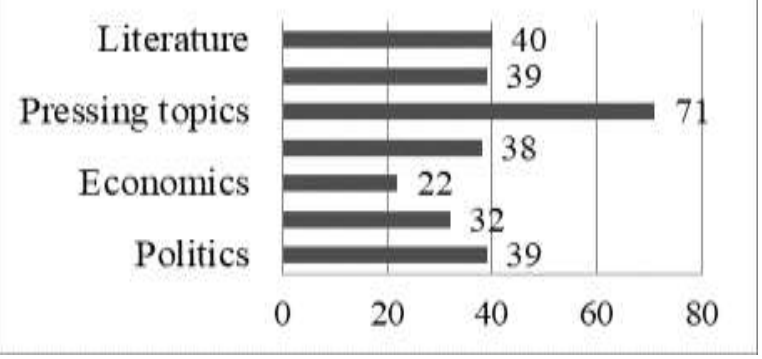

Figure 3. Most interesting topics in European languages.

The third place is taken by: popular science topics - 38\%, history $-32 \%$ - in classes of European languages, and literature $-35 \%$, popular science $-27 \%$ - at Oriental languages lessons. At the bottom of the list of the most interesting topics respondents named economics $-22 \%$ and $26 \%$ (West European and Oriental languages respectively).

Two of the questions were aimed at finding out the teacher personality type (democratic or authoritarian) which the students find most conducive to language learning (Figure 4) and the teaching style they have encountered most often (Figure 5).

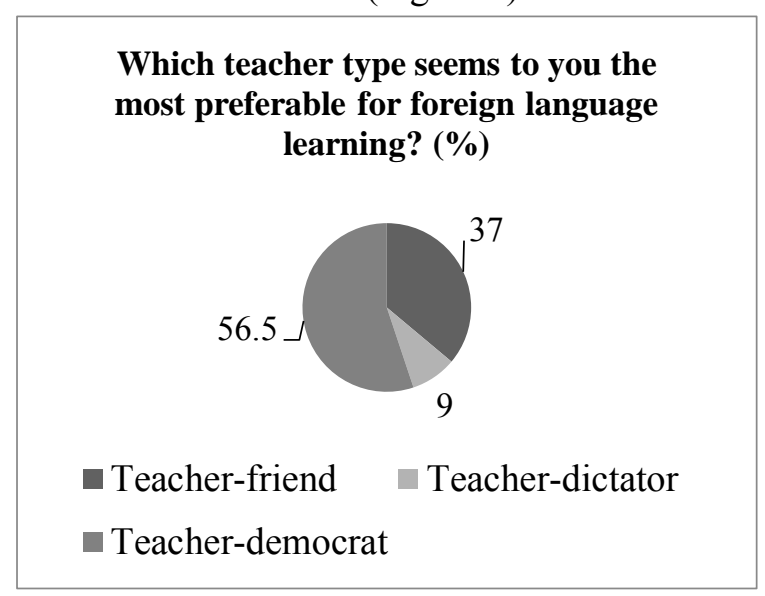

Figure 4. Teacher type that seems the most preferable for foreign language learning.

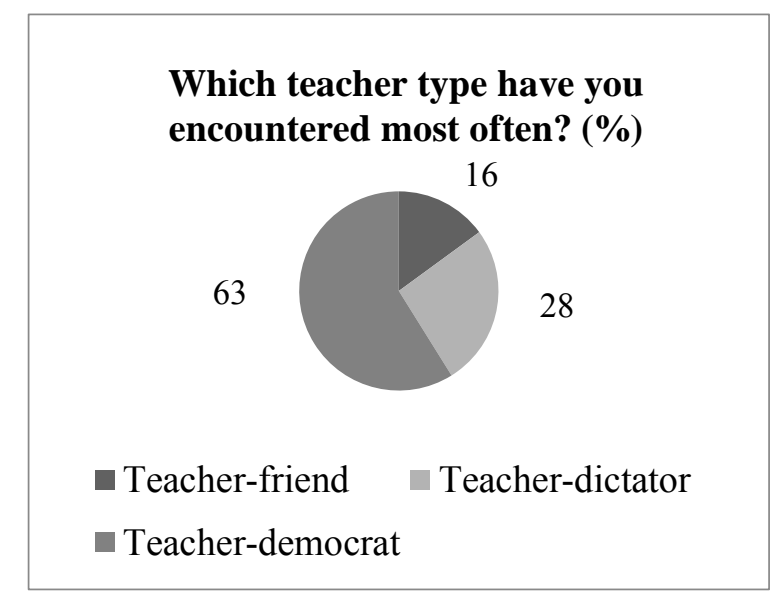

Figure 5. Teacher type you have encountered most often.

What would rather motivate you to engage in communication in a foreign language in class?

- Wish to get a good grade/credit/exam - 13 persons (17\%)

- Wish to make a good impression on the teacher -10 persons. (13\%)

- Interesting topic -60 persons. (79\%)

- General atmosphere in class - 51persons. (67\%)

- Diligence as a personality trait -17 persons. $(22 \%)$

- Wish to perfect the language -46 persons. $(60.5 \%)$

- Something else: the wish to express own ideas, classmates, thought of moving to Great Britain.

As far as gender differences are concerned, the results of the survey showed the following:

1. The question "Which type of teacher seems to be the most preferable for learning a foreign language?" yielded the following results (Figure 6):

Teacher-friend - 28 persons (37\%), females- $21(39 \%)$, males $-7(33 \%)$.

Teacher-dictator -7 persons $(9 \%)$, females $-6(11 \%)$, males $-1(5 \%)$.

Teacher-democrat -43 persons $(56.5 \%)$, females $-29(54 \%)$, males $-14(66 \%)$. 
2. The question "Which teacher type have you encountered most often?" (Figure 7):

Teacher-friend - 12persons, (16\%), females -10 (18\%), males - $2(9.5 \%)$.

Teacher-dictator - 21 persons, (28\%), females - $13(24 \%)$, males $-8(38 \%)$.

Teacher-democrat - 48persons, (63\%), females - $35(65 \%)$, males - $13(62 \%)$

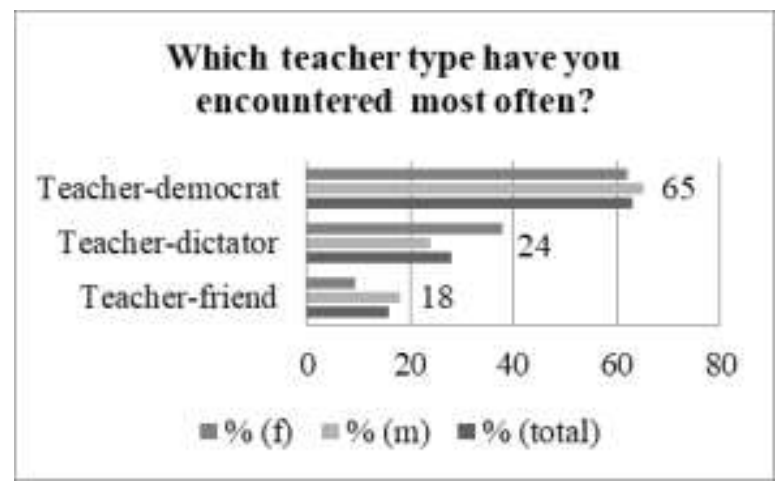

Figure 6. The most preferable type of teacher.

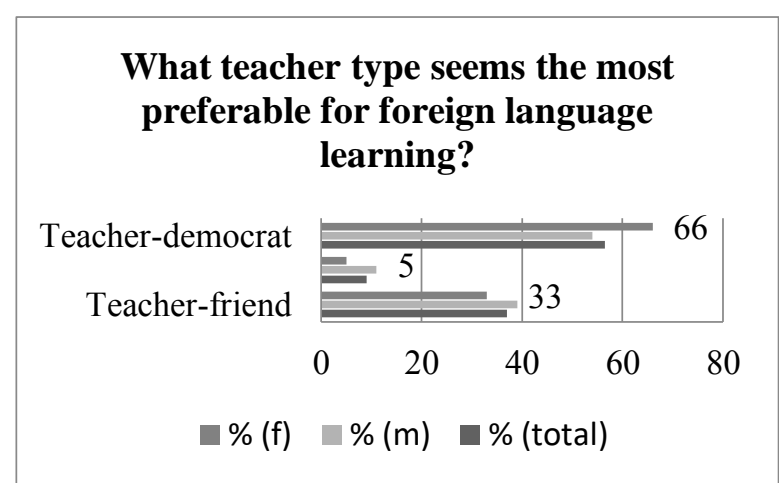

Figure 7. Teacher type you encountered most often.

3. What would rather motivate you to engage in communication in a foreign language in class (Figure 8)?

Wish to get a good mark/credit/exam - 13 persons, (17\%), females - $12(22 \%)$, males $-1(5 \%)$.

Wish to make a good impression on the teacher -10 persons $(13 \%)$, females $-9(17 \%)$, males $-1(5 \%)$. Interesting topic -60 persons (79\%), females $-42(78 \%)$, males $-18(86 \%)$.

General atmosphere in class - 51persons, $(67 \%)$, females - $36(67 \%)$, males $-15(71 \%)$.

Diligence as a personality trait -17 persons $(22 \%)$, females $-14(26 \%)$, males $-3(14 \%)$.

Wish to improve the language -46 persons $(60.5 \%)$, females $-33(61 \%)$, males $-13(62 \%)$.

Something else: wish to express own ideas, group mates, thoughts of moving to Great Britain.

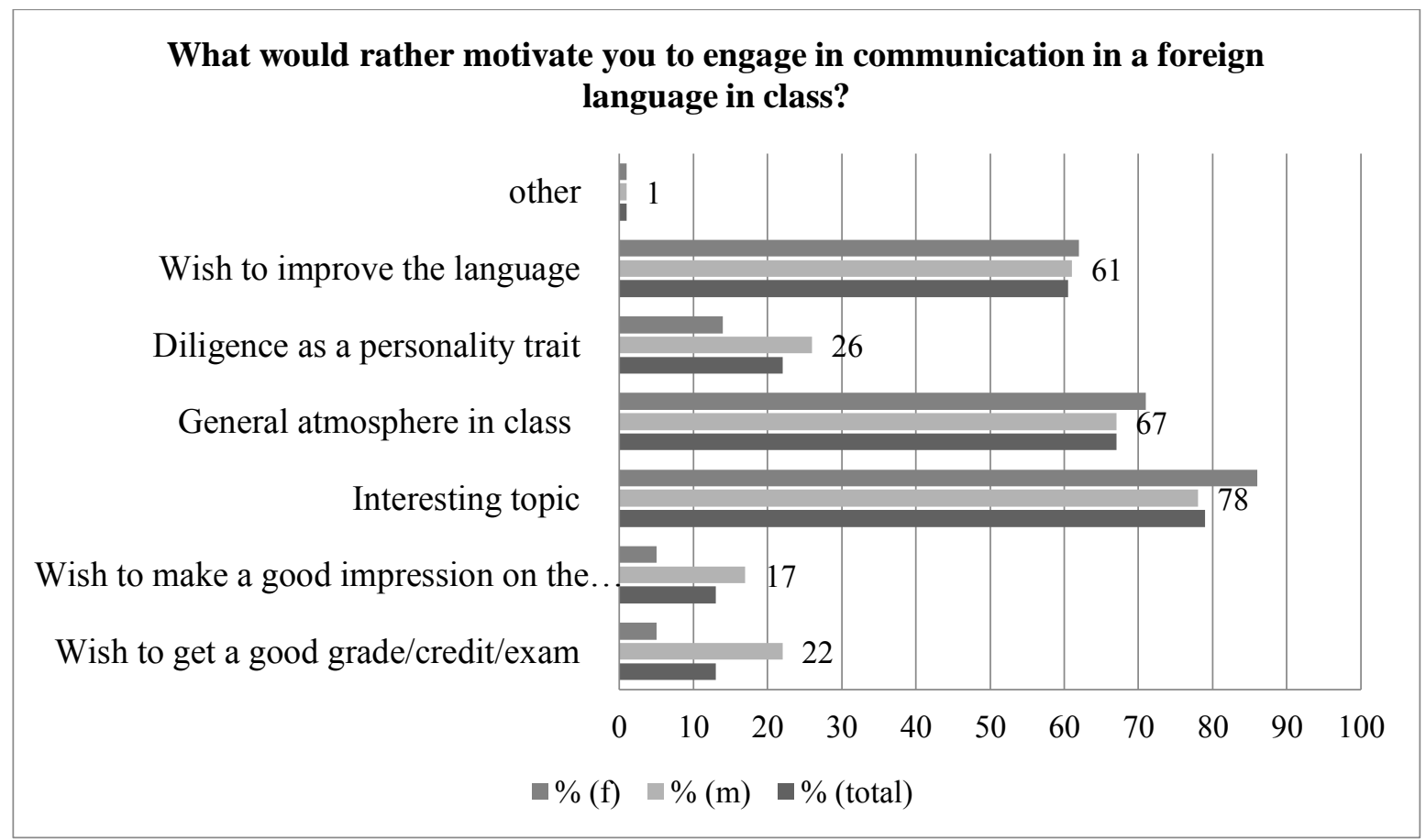

Figure 8. Motivating factors in a foreign language class.

\section{Conclusions}

The results of the survey suggest the following conclusions.

- For tertiary students' intrinsic motivation is the prevalent form of motivation, i.e. the wish to improve and perfect languages accounts for the majority of responses, which can be interpreted 
as an understanding by the students of the instrumental value of foreign languages in their future employability.

- The role of teacher is of significant importance in providing a supportive general atmosphere in class and relevant materials and topics for studying and discussing.

- It might be worthwhile to conduct differentiated studies aimed at respective specialties, e.g. separately for history students or economics students, etc.

- Averaged data for all the four specialties demonstrates that the learners, regardless of the language (Oriental or European) are strongly attracted by topics common to all mankind which pertain to the key issues of the present.

- If one puts aside economics (for students majoring in it) and politics (for future political scientists), it is possible to see a typical picture of modern youth's interests - pressing contemporary issues, literature, everyday life.

- The gender differences do not seem conclusive just because there happened to be many more female students among the respondents. It would be interesting to conduct a survey on a group with a more even gender distribution to explore the motivating factors related to sexes.

- It would be also interesting to focus future research on such aspects of teacher personality as democratic versus authoritarian types. What exactly does it mean to be a democratic teacher? Besides, it would be challenging to try to find out if a language taught professionally somehow affects the teacher. Does the culture of the language - a European one versus an Oriental one influence the teacher who is not a native speaker?

- In the modern educational process, it is important to retain the learner's interest in studying a foreign language. The most essential component of fostering this interest is a motivational aspect, the inner force urging the student to master a foreign language, and in our case, several foreign languages simultaneously, and creating positive attitudes to learning, which in its turn helps achieve certain goals and opens up doors to a professional carrier in society.

\section{Bibliography}

1. Cantrell R.P., Stenner A.J., Katzenmeyer W.G. (1977). Teacher Knowledge, Attitudes, and Classroom Teaching Correlates of Student Achievement. Journal of Educational Psychology, 69(2), 172-179.

2. Cazden C.B. (2001). Classroom Discourse: The Language of Teaching and Learning. (2 $2^{\text {nd }}$ ed.). Portsmouth, NH: Heinemann.

3. Dornyei Z. (1994). Motivation and Motivating in the Foreign Language Classroom. The Modern Language Journal, 78(3), 273-284.

4. Dornyei Z. (1998). Motivation in Second and Foreign Language Learning. Language Teaching, 31(3), $117-135$.

5. Dornyei Z. (2011). Teaching and Researching Motivation. ( $2^{\text {nd }}$ ed.). Edinburgh Gate, England: Pearson Education.

6. Dornyei Z., Csizer K. (1998). Ten Commandments for Motivating Language Learners: Results of an Empirical Study. Language Teaching Research, 2(3), 203-229.

7. Gardner R.C. (1985). Social Psychology and Second Language Learning: The Role of Attitudes and Motivation. London: Edward Arnold.

8. Gardner R.C. (2001). Language Learning Motivation: The Student, the Teacher, and the Researcher. Texas Papers in Foreign Language Education, 6 (1), 1-18.

9. Gardner R.C., Lambert W.E. (1972). Attitudes and Motivation in Second Language Learning. Rowley, MA: Newbury House Publishers.

10. Hamann D.L., Baker D.S., Mcallister P.A., Bauer W.I. (2000). Factors Affecting University Music Students' Perceptions of Lesson Quality and Teaching Effectiveness. Journal of Research in Music Education, 48(2), 102-113.

11. MacIntyre P.D., Clement R., Dornyei Z., Noels K.A. (1998). Conceptualizing Willingness to Communicate in a L2: A Situational Model of L2 Confidence and Affiliation. The Modern Language Journal, 82(4), 545-562.

12. Madsen C. K., Standley J. M., Cassidy J. W. (1989). Demonstration and Recognition of High and Low Contrasts in Teacher Intensity. Journal of Research in Music Education, 37, 85-92.

13. Madsen K. (2003). The Effect of Accuracy of Instruction, Teacher Delivery, and Student Attentiveness on Musicians' Evaluation of Teacher Effectiveness. Journal of Research in Music Education, 51(1), 38-51.

14. Polk J.A. (2006). Traits of Effective Teachers, Arts Education Policy Review, 107(4), 23-29.

15. Sanders W.L., Horn S.P. (1998). Research Findings from the Tennessee Value-Added Assessment System (TVAAS) Database: Implications for the Educational Evaluation and Research. Journal of Personnel Evaluation in Education, 12(3), 247- 256. 